\title{
Volunteer Driving Program
}

National Cancer Institute

\section{Source}

National Cancer Institute. Volunteer Driving Program. NCI Thesaurus. Code C159753.

A transportation service where volunteers provide rides. 